\title{
STEREOTYPY O ŽIDOCH V SLOVENSKEJ LITERATÚRE Z OBDOBIA PRED DRUHOU SVETOVOU VOJNOU
}

\author{
MONIKA ADAMICKÁ
}

\begin{abstract}
Adamická, Monika: Stereotypes of Jews in the Slovak Literature Before the World War II, 2019, Vol. 1, Issue 2, pp. 56 - 61. DOI: 10.17846/CEV.2019.01.2.56-61.
\end{abstract}

ABSTRACT: This paper deals with the depiction of Jewish themes in Slovak literature from the end of the 18th century until 1939 - the beginning of World War II, which fundamentally changed the view on Jewry. It points on the prevailing stereotypes about Jews in Slovak literature from this period, mainly the stereotype of Jew - trader and wandering Jew - Ahasver, which reflected the attitude of Slovaks towards Jews and which led to the formation of ideas of anti-Semitism in Slovak society.

KEYWORDS: Antisemitism. Jewry. Stereotype. Slovak Literature. Pre-War Period.

Tematika židovstva sa v slovenskej literatúre zjavuje už v období klasicizmu. Židia sa dostávajú do širšieho povedomia po vydaní Tolerančného patentu Jozefom II. v roku 1781. Dôvodom vydania patentu bola snaha vyrovnat' sa s existenciou evanjelického náboženstva. Tolerančný patent povoloval okrem katolíckeho vierovyznania aj luteránske, kalvínske a ortodoxné. Bolo to však len na báze tolerovania, veriaci sa mohli slobodne hlásit $k$ svojmu vierovyznaniu, ale nie na báze rovnoprávnosti náboženského vierovyznania. 2. januára 1782 sa Tolerančný patent začal vzt’ahovat’ aj na židovskú vieru. Židia tým získali väčšie práva, mohli sa napr. venovat väčšine slobodných povolaní, študovat’ na univerzitách či vlastnit pôdu. Nemohli však pracovat v štátnych službách.

Od obdobia klasicizmu sa teda v slovenskej literatúre stretávame s obrazom Žida, pričom pohlad na židovstvo a obraz Žida sa v priebehu storočí a vplyvom dejinných udalostí mení, tak, ako sa mení aj postavenie židovstva $\mathrm{v}$ slovenskej spoločnosti. Kým v období pred druhou svetovou vojnou v literatúre prevládajú negatívne stereotypy o Židoch vyplývajúce najmä z ich majetkových pomerov, po druhej svetovej vojne sa do popredia diel so židovskou tematikou dostáva problematika šoa (holokaust). Vo všeobecnosti by sa teda dalo povedat, že zlomovým bodom v zobrazovaní židovskej tematiky v literatúre bola 2 . svetová vojna a s ňou spojený holokaust, ktoré zásadným spôsobom zmenili postoj spoločnosti k židovstvu.

V súvislosti so zobrazovaním Židov v slovenskej literatúre obdobia pred druhou svetovou vojnou by sa dalo hovorit’ o určitých stereotypoch, ktoré sa v dielach opakujú, a ktoré napokon odzrkadlujú aj postoj slovenskej spoločnosti voči Židom. Stereotypy možno charakterizovat ako určité zovšeobecnenia o istých skupinách ludí, ktoré vypovedajú o rôznych formách správania sa danej spoločenskej skupiny, o ich typických vlastnostiach. V prípade židovstva panoval v slovenskej spoločnosti v období pred druhou svetovou vojnou stereotyp, ktorý sa spájal s ich majetkovými pomermi, s ich obchodnou činnostou, vdaka ktorej nadobúdali stále väčšie majetky. „Okrem stereotypného „obchodníka“ sa na scéne objavuje bankár, továrnik, ale aj lekár, právnik či umelec židovského pôvodu“ (Hrbáček 2018, 100). Stereotyp o Židoch ako obchodníkoch sa následne spája aj s chamtivostou, lakomstvom a prefíkanostou.

Pred druhou svetovou vojnou sa stretávame v literatúre s vykreslením Žida ako drobného vidieckeho obchodníka, krčmára, či úžerníka, v niektorých prípadoch sa v jednej osobe stretávame aj s kombináciou týchto troch typov. Žid tu vystupuje ako človek, ktorý vyniká obchodníckymi schopnostami, profituje prostredníctvom úžery na neštastí slovenského ludu, je príčinou pádu slovenského človeka. 
Dalo by sa povedat', že väčšinu diela, v ktorých je dominantným motívom židovstvo, či len okrajovo spomenutá židovská problematika obdobia pred druhou svetovou vojnou, spájajú dva hlavné motívy. Prvým motívom je vykreslenie Žida, ktorý žije na úkor zbedačeného, alkoholom skazeného slovenského ludu. Toto postavenie Slováka autori vidia práve v jeho biede, ktorá je aj príčinou, prečo sa utieka k alkoholizmu, prečo je nútený si požičiavat peniaze od Žida, krčmára a obchodníka, a čo ho v konečnom dôsledku vedie do ešte väčšej biedy. $V$ tomto prípade dominuje v dielach stereotyp Žida - obchodníka, ktorý sa spája so stereotypom vzdelaného Žida.

Druhým motívom je explanácia, prečo sa Žid správa týmto spôsobom, prečo sa venuje obchodu, krčme, namiesto toho, aby vykonával prácu ako sedliak, obrábal pôdu a vykonával práce okolo svojho hospodárstva. Dôvodom je, že Židia nežijú vo vlastnej krajine, nemajú svoj štát, svoju domovinu, na cudzom území sa cítia akoby v zajatí. Autori predvojnového obdobia sa snažia nájst’ východisko $\mathrm{z}$ tejto situácie. $\mathrm{V}$ dielach s týmto motívom možno hovorit’ o stereotype, ktorý vychádza z mýtu o putujúcom Židovi - Ahasverovi.

\section{ŽID - OBCHODNÍK, KRČMÁR A LAKOMEC}

Stereotyp Žida - obchodníka vyplýva z toho, že židovské rodiny sa zaoberali prevažne obchodnou činnostou. Po vydaní Tolerančného patentu mala ich obchodná činnost̉ vzostupnú tendenciu, $\mathrm{v}$ dôsledku čoho dochádzalo aj k nárastu ich majetku. S obchodnou činnostou alebo so židovským obchodným duchom sa paralelne stretávame aj s „heteroimage“ vzdelaného Žida. Obraz vzdelaného Žida vyplýva zo samotnej podstaty judaizmu, z ich koncepcie celoživotného vzdelávania a z Mojžišovho nariadenia vzdelávat’ sa, odovzdávat' svoje poznatky det’om. Židia v Uhorsku, kedže súčasné slovenské územie bolo v 19. storočí a na začiatku 20. storočia súčastou Habsburskej monarchie, patrili k občanom Uhorska s vysokou úrovňou vzdelanosti. Podla štatistiky z roku 1910 až 90 \% Židov v tom období vedelo čítat a písat' (Lendvai 2011, 304). Súčasne do značnej miery kontrolovali uhorský finančný systém a moderné odvetvia priemyslu. 19. storočie sa nieslo v znamení Velkej priemyselnej revolúcie, ktorá priniesla zmeny vo výrobe, a v konečnom dôsledku aj v spoločnosti. Na tieto zmeny najdynamickejšie reagovali v Uhorsku práve Židia. V súvislosti s pozitívnym pôsobením židovskej minority v uhorskej spoločnosti Paul Lendvai vo svojej knihe Mad’ari, konštatuje: „No v neposlednom rade Budapešt môže vd’ačit Židom za to, že v kultúrnej, vedeckej, ako aj vo finančnej oblasti boli nositel’mi pokroku, následkom čoho sa Budapešt stala na východ od Viedne najväčším finančným a mediálnym centrom“ (Lendvai 2011, 304). Ich hospodársky a ekonomický prínos pre Uhorsko vyplýval z ich orientácie na úspech a dosahovanie zisku. Prínos Židov nespočíval len v oblasti hospodárskej a ekonomickej, ale aj v oblasti vedy, umenia, literatúry a printových médií. Ako príklad možno uviest’ množstvo denníkov, ktoré v Budapešti vychádzali, a to tridsat'devät. Na porovnanie, vo Viedni vychádzalo len dvadsaťštyri denníkov a v Londýne dvadsatpät. Gradujúci antisemitizmus v Uhorsku však práve tieto pozitívne vlastnosti Židov, ktoré viedli k prosperite krajiny, zámerne hyperbolizovali a následne sa v uhorskej spoločnosti (aj v slovenskej ako súčasti uhorskej spoločnosti) postupne etablovali negatívne stereotypy o Židoch vyplývajúce z ich majetkových pomerov (stereotyp o židovskom obchodnom duchu, Židovi - krčmárovi).

S postavou Žida - krčmára sa stretávame už v prvom slovenskom, dvojzväzkovom románe Jozefa Ignáca Bajzu, Príhody a skúsenosti mládenca Reného, ktorý bol vydaný v rokoch 1784 1785. Žid - obchodník sa tu spája s postavou Žida, majitela krčmy. Tento židovský stereotyp je spätý s alkoholizmom a biednym postavením slovenského národa. Autor tu alkoholizmus Slovákov zdôvodňuje ako dôsledok ich biedneho postavenia, z čoho pramení aj ich zadlženost’ u Žida. „Nezadlžili sme sa pitím, to najmenej, ale bežíme za ním pripretí kadejakou psotou a ked” už nemáme na výber nič iné" (Bajza 1970, 294). Na druhej strane, Židia sa ani netaja tým, že 
nadobudli majetok práve úžerou, podvodom. „Mnohí Židia sami potvrdzujú, že nadobudli majetok klamstvom, okrádaním a zderstvom" (Bajza 1970, 295).

Žid - krčmár sa objavuje aj v dielach Jonáša Záborského. V diele Dva dni v Chujave z roku 1873 sa opätovne stretávame so stereotypom Žida, majitela krčmy, ktorý profituje na zlom spoločenskom položení Slováka. Autor sa kriticky stavia voči slovenskej spoločnosti, kritizuje ich za ich alkoholizmus, z čoho následne profitujú najmä Židia, ktorí sú vlastníkmi krčiem. Okrem Židov zdiera zbedačený slovenský lud aj vrchnost', ktorá to odôvodňuje tým, že ak nevezmú oni, o všetko, o celý majetok pripravia dedinčanov Židia. „Myslia si: čokolvek im necháme, vezmú židia; teda len ber!“ (Záborský 1963, 99). Autor vkladá do dialógov postáv silné antisemitské idey, najmä čo sa týka autorovho riešenia alebo východiska $\mathrm{z}$ tejto situácie, ktoré vidí v odchode Židov zo Slovenska zhabaním ich majetku, resp. v obmedzení Židov rozširovat svoje majetky. V závere knihy Rastic konštatuje: „... plemeno židovské je vykorenené okrem toho vel'komožného v kaštieli. Ked'sme im odobrali krčmy, jatky, predali aj osminy a vypratali sa. Bo žid bez krčmy, jatky a čachrov nebude“ (Záborský 1963, 152). Marginálne sa postava Žida - krčmára objavuje aj v Záborského diele Faustiáda, v narácii o neštastnej žene - pijanke, ktorá do židovskej krčmy prišla prepit aj posledné zvyšky svojho majetku.

Stereotyp Žida - obchodníka je dominantným v poviedke Jozefa Gregora Tajovského Ǔžerník. Nejde však o obraz Žida ako majitel’a obchodu alebo krčmy, dalo by sa povedat', že problematika alkoholizmu slovenského národa je v tejto poviedke druhoradá, hoci motív alkoholizmu sa vo velkej miere objavuje v dielach slovenských autorov, nielen v dielach so židovskou tematikou. Židovský zmysel pre obchod je tu spojený skôr s obchodným duchom, vypočítavostou Žida, majitela rozsiahleho panstva, ktorý zo strachu pred stratou vlastného imania počas neúrodného roka neváhal podpálit svoj statok, aby získal peniaze $\mathrm{z}$ poistky. $\mathrm{V}$ tomto prípade sa stretávame so stereotypom Žida - úžerníka. Autor v poviedke prináša určitú reflexiu nad biednym postavením Slováka, pričom príčinu tohto stavu vidí práve v typicky židovských vlastnostiach, v židovskej chamtivosti, honby za majetkom. „Majú celé stráne, a ty potíkaš sa po tom šírom svete, žena s detimi doma mozolí, a máš záhon na kosisko" (Tajovský 1965, 155). Negatívny pohlad na židovstvo pramení podla Tajovského vo vel'kých majetkových rozdieloch medzi Židmi a Nežidmi.

Chamtivost', lakomstvo, ako typickú židovskú charakteristiku zobrazuje aj Jonáš Záborský v diele Faustiáda (1866). Dielo je satirou na uhorské pomery v 50. - 60. rokoch 19. storočia. Nejde tu však len o výsmech židovstva, autor sa vysmieva všetkým, Nemcom i Slovákom, Židom rovnako ako antisemitom, ale aj iným náboženstvám a etnikám. Židovstvo je tu spojené so stereotypom lakomca, ktorý sa ženie za majetkom. Vystihuje to príhoda s Towiańskym, ktorý Židom povedal, že sa bude dávat do prenájmu manna nebeská. „Do židov akoby hrom uderil. V̌setci sa zdvihli a ponáhlali sa rýchle na dražbu“ (Záborský 1984, 26). Autorov postoj k židovstvu najviac vystihuje myšlienka: „Všetci židia boli predtým v zajatí jedného národa, teraz sú všetky národy v zajatí židov“ (Záborský 1984, 26).

Postava Žida - lakomca je zobrazená aj v diele Gejzu Vámoša Odlomená haluz z roku 1934. Ide vôbec o prvé dielo autora židovského pôvodu, v ktorom zobrazuje práve židovský fenomén. Preto aj jeho spôsob reflexie o židovskej otázke obdobia pred holokaustom je do istej miery obhajujúci, hoci sa o Židoch vyjadruje sarkasticky, ba až kriticky (o ich spôsobe života a náboženskom fanatizme, o židovských náboženských rituáloch a praktikách), za čo ho židovská obec chcela vylúčit. Po nástupe Hitlera k moci však aj sám na sebe zacítil vlnu antisemitizmu. Podarilo sa mu zachránit’ sa útekom zo Slovenska v roku 1939 do Číny, neskôr do Brazílie, kde strávil zvyšok života. Napriek tomu, že sa kriticky stavia k niektorým aspektom praktického života Židov, židovstvo ako také neodsudzuje, skôr obhajuje, hladá spôsoby, ako využit pozitívne vlastnosti Židov pre slovenskú spoločnost', a naopak, ako dokáže spolužitie Židov s Nežidmi ovplyvnit spôsob ich života v pozitívnom zmysle. Hned’v prvej časti románu sa stretávame so stereotypom Žida ako lakomca, ked’ sa 
pri pochovávaní robustnej Židovky použije truhla z lacných, tenkých dosák a tá sa pri pochovávaní rozlomí. S vykreslením Žida ako lakomca sa stretávame aj v postave holiča Šumichrasta. „Je taký lakomý, šeptali o ňom, že dvakrát zje šošovicu a predal by kosti svojho nebohého deda, keby mu rabín dovolil, aby ho vyhrabal" (Vámoš 1969, 83).

\section{AHASVER - PUTUJÚCI ŽID}

Druhý dominantný stereotyp putujúceho Žida súvisí s mýtickým príbehom o Ahasverovi, ktorý žil v časoch Ježiša Krista. Podla biblického mýtu Ahasver odmietol poskytnút hoci aj krátky odpočinok pred svojím domom Ježišovi Kristovi pri jeho krížovej ceste na Golgotu, v dôsledku čoho ho Kristus odsúdil na večné putovanie po zemi až do svojho druhého príchodu na zem. Tým bol Ahasver Kristom vyhnaný zo svojej domoviny, stal sa z neho večne putujúci Žid bez domova, ktorý sa v každej krajine cítil ako cudzinec, nedokázal sa asimilovat’ s domácim majoritným etnikom.

Tento stereotyp o večne putujúcich Židoch bez vlastnej domoviny, ktorí nie sú schopní asimilácie v cudzej krajine, však neplatil globálne. Príkladom úspešnej asimilácie Židov v „cudzom“ prostredí sú Židia v Uhorsku. Paul Lendvai vo svojej knihe píše: „...nikde, ani vo východnej, južnej či strednej Európe, sa dva národy natolko vzájomne neprelínali ako v Uhorsku“ (Lendvai 2011, 301). Dokonca po prijatí emancipačného zákona o menšinách v roku 1867 sa vel'ká časṫ Židov prihlásila za príslušníkov mad’arského národa. To, čo charakterizovalo Židov, nebola ani národnost', ani jazyk, ale konfesia. A práve uhorskí (madarskí) Židia sa po rozpade Rakúsko-Uhorska stali terčom najsilnejších antisemitských prejavov z dôvodu, že v nástupníckych štátoch Uhorska (Rumunsku, Československu a Juhoslávii) neboli ochotní sa zaradit medzi majoritné etnikum, nad’alej sa správali ako hrdí Mad’ari.

So stereotypom putujúceho Žida, ktorý sa cíti cudzo v novej domovine sa stretávame už v románe Jozefa Ignáca Bajzu. Autor interpretuje konanie Židov, ktoré má negatívny dopad na slovenskú spoločnost', ako dôsledok ich domnelého zajatia v cudzom štáte, ktorý nie je ich pôvodnou domovinou. $\mathrm{V}$ dôsledku toho nemajú záujem o prácu v polnohospodárstve, ale radšej sa venujú obchodu. Bajza toto tvrdenie istým spôsobom neguje, berie to skôr ako ich výhovorku. „Nuž, či sa im aj v zajatí nechce jest', alebo či v Egypte a Babylone neobrábali zem? Je to iba výmysel rabínov..." (Bajza 1970, 296). Autor tu berie za príklad udalosti vyobrazené vo Svätom Písme, kedy boli Židia v egyptskom a babylonskom zajatí, napriek tomu sa museli venovat' obrábaniu zeme. Naopak, zajatie, v akom sa nachádzali vo vtedajšej dobe, bolo len zajatie domnelé, zakladalo sa len na ich pocite zajatia. Nevidí teda dôvod, prečo by nemohli zmenit’ spôsob svojho života.

Špecifickým príkladom zobrazenia stereotypu putujúceho Žida je dielo Gejzu Vámoša Odlomená haluz. Typom Žida Ahasvera je v tomto románe slovenský Žid, ktorému sa ani v priebehu dlhých storočí nepodarilo dostat’ do inklúzie v rámci slovenskej spoločnosti. Jednotlivé dejové sekvencie románu sú doplnené reflexiami o postavení a pôsobení Židov v slovenskej a madarskej spoločnosti, o ich charakterových vlastnostiach. Kým slovenského Žida vykresluje ako lakomca, človeka chladného, vypočítavého, zaujímajúceho sa len o svoj obchod, mad’arský Žid tu vystupuje ako človek ludský, dobrosrdečný. „Mad’arský žid, plný írečitého ludového humoru, dobrých náklonností a srdečných úmyslov, s hrôzou a nechápavo pozeral na svojho horniackeho súverca. Zdal sa mu chladným, vypočítavým, prefíkaným, l’ahostajným ku všetkému okrem obchodu, v ktorom je pravým nemilosrdným vydriduchom, idúcim cez mŕtvoly“ (Vámoš 1969, 101). Vysvetluje to tým, že Židov spája výlučne ich náboženská viera, ostatné črty povahy sa formujú podla toho, kde žijú. Ich charakter sa formuje pod vplyvom národa tej ktorej krajiny, v ktorej žijú, okrem vzorcov správania preberajú aj domorodý jazyk. Najviac vidno asimiláciu práve u mad’arského Žida. „Madarský žid stal sa vzorom takmer úplnej asimilácie“ (Vámoš 1969, 102). Naproti tomu, so slovenským 
prostredím sa Židia nezžili takmer vôbec, prebrali jedine slovenskú reč, aj to len dialekt tohto jazyka, nie jeho spisovnú formu. Žid v slovenskom prostredí teda nie je ani Slovákom, ale nehlási sa ani k Mad’arom a dokonca ani k Židom. „Horniacky žid nestal sa Madiarom, nebol Slovákom a ani židom. Bol iba kupcom“ (Vámoš 1969, 103).

Myšlienky asimilácie Židov s dominantným etnikom sa nachádzajú aj v diele súčasného slovenského autora Antona Baláža, konkrétne v poviedke so židovskou tematikou Šimon Pútnik zo zbierky Portréty prežitia (2014). Baláž sa však venuje asimilácii Židov v povojnovom období, $\mathrm{v}$ podmienkach československého socialistického zriadenia. Snaha o splynutie pramenila najmä z prežitých hrôz holokaustu. Nechceli byt’ viac iní, odlišovat’ sa od ostatných, preto zvolili cestu splynutia s inými. „Pretože práve odlišnost, odlišnost' ich dejín, ich viery, odlišnost' v oblečení, vo výzore, v jedlách, sviatkoch a uvažovaní, tá odlišnost' vždy dráždila a provokovala“ (Baláž 2014, 256). V povojnovom období nabádal Židov k asimilácii aj nový režim. Baláž vo svojej poviedke píše: „Aj režim, v ktorom žili, ich nabádal, aby nevyčleňovali svoje utrpenie z utrpenia celého ludu, aby ho internacionalizovali“ (ibid.). Židia po prežitých hrôzach rasového prenasledovania boli otvorení svojmu splynutiu s československou spoločnostou. „A oni naozaj nechceli byt už viac výnimkou" (ibid.).

Na základe interpretácie vybraných diel od konca 19. a začiatku 20. storočia, v ktorých sa vyskytuje tematika židovstva, či ako hlavná téma, alebo len marginálne, možno pozorovat takmer totožné stereotypy o Židoch, ktoré vyznievajú silne antisemitsky. Spoločným, prevládajúcim stereotypom je zobrazenie Žida ako krčmára, ktorý sa spolupodiela na zlom ekonomickom postavení slovenského národa. V diele Jozefa Ignáca Bajzu a Gejzu Vámoša je tento stereotyp vysvetlený ako dôsledok toho, že Židia nežijú vo svojej krajine. Z toho vyplýva ich nezáujem o dianie v krajine, resp. na území, na ktorom žijú Slováci. Gejza Vámoš okrem toho vidí problém aj v tom, že Žid na Slovensku sa neasimiloval s dominantným etnikom. Pre Vámoša je Žid v slovenskom prostredí len kupcom, človekom bez príslušnosti k akejkolvek národnosti. Protikladom k Židovi na Slovensku je madarský Žid, ktorý je príkladom úplnej asimilácie, preto jeho inakost’ neprovokuje dominantné etnikum. Dôvodom tohto rozdielu medzi asimilovaným madarským Židom a neasimilovaným slovenským Židom môže byt’ rozdielnost historického vývoja oboch národov. Kým mad’arský (uhorský) štátny útvar, či už to bolo královstvo alebo republika po roku 1918, mal dlhoročnú tradíciu samostatného štátu so silnou národnou identitou (nepretržite od roku 1001, kedy vzniká Uhorské královstvo, s výnimkou obdobia Habsburskej rakúsko-uhorskej monarchie po roku 1526), Slovensko ako súčast Československa malo v dobe vzniku diela (1934) len 16-ročnú históriu samostatného štátneho útvaru.

S podobným chápaním židovstva, ako bolo zakorenené v slovenskej spoločnosti predvojnového obdobia, sa stretávame aj v ideológii nacizmu, podla ktorého je pôvodcom všetkého zla v krajine Žid, úhlavný nepriatel árijskej rasy. Žid povýšil záujem o jednotlivca na najvyššiu hodnotu, nezaujímal sa o celok, o národ, ako je tomu v prípade árijskej rasy. Demonštrujú to aj slová Františka Bauera v knihe Mein Kampf očima historikư, ktorá je akýmsi výkladom diela Mein Kampf Adolfa Hitlera: „Židé jsou parazity národi̊. Žid žil a žije vždycky jen jako př́živník na těle jiných národi a využivá plodů jejich práce“ (Bauer a kol. 2008, 82). Podla Hitlera sa Židia najprv infiltrovali medzi nemecký národ ako šikovní obchodníci, následne si začali vytvárat’ vo vnútri nemeckého štátu svoj vlastný štát, nadobúdajú stále väčšie majetky, zbedačujú nemecký národ úžerníctvom. V Hitlerovej koncepcii teda vidiet istú paralelu s antisemitskými stereotypmi, ktoré panovali medzi Slovákmi. Na druhej strane v diele Dva dni v Chujave od Jonáša Záborského sa nachádzajú aj myšlienky arizácie židovského majetku ako možného riešenia židovskej otázky, ked’ autor píše: „Ked’sme im odobrali krčmy, jatky, predali aj osminy a vypratali sa. Bo žid bez krčmy, jatky a čachrov nebude“ (Záborský 1963, 152). 
Na základe antisemitských postojov slovenskej spoločnosti voči Židom v období pred druhou svetovou vojnou možno nájst' dôkaz toho, že pogrom na Židoch, alebo snaha o konečné riešenie židovskej otázky, neboli len v záujme Nemcov. Podobne sa k tejto problematike stavali aj iné európske krajiny, predovšetkým krajiny východnej Európy (Wistrich 2002, 33).

\section{SUMMARY}

Based on the interpretation of the works of Slovak literature, it can generally be stated that in these works from the period before World War II. stereotypes about Jews could be found. But it was not only a literary representation, but the stereotypes also occurred in Slovak society and were a source of formation of anti-Semitism. Increasing the spread of the ideas of anti-Semitism and their acceptance by Slovak society led to the situation, that people felt hatred towards the Jews. And as it is known from history, hatred towards the Jews led to their mass murder. The World War II. and the Holocaust horror were also signed under the perception of Jewry. While before the war the Jews were described in a negative way in the literature, as the greedy people, the good merchants, whose only aim is their own benefit, after the war, these stereotypes have become secondary. The picture of Jews in the post-war period is linked with the theme of mass murder of them in the Nazi concentration camps.

Štúdia vznikla v rámci riešenia projektu UGA X/1/2019 s názvom Problematika povojnového židovstva $v$ slovenskej literatúre s dôrazom na tvorbu Antona Baláža.

\section{LITERATÚRA}

Bajza, Jozef Ignác, 1970. Príhody a skúsenosti mladíka Reného. Bratislava: Tatran.

Baláž, Anton, 2014. Portréty prežitia. Bratislava: MilaniuM.

Bauer, František, a kol. 2008. Mein Kampf očima historikü. Praha: Nakladatelství XYZ.

Hrbáček, Magdaléna, 2018. Vybrané židovské stereotypy v strednej Európe. In: Zelenka, Miloš Tkáč-Zabáková, Lenka (eds.): Imagológia ako výskum obrazov kultúry (K reflexii etnických stereotypov krajín V4). Nitra: Univerzita Konštantína Filozofa, 97 - 103.

Lendvai, Paul, 2011. Madiari. Bratislava: Kalligram.

Tajovský, Jozef Gregor, 1965. Tajní boháči. Bratislava: Slovenské vydavatel’stvo krásnej literatúry.

Vámoš, Gejza, 1969. Odlomená haluz. Bratislava: Smena.

Wistrich, Robert S., 2001. Hitler a holokaust. Bratislava: Slovart.

Záborský, Jonáš, 1963. Dva dni v Chujave. Bratislava: Slovenské vydavatel'stvo krásnej literatúry.

Záborský, Jonáš, 1984. Faustiáda. Bratislava: Tatran.

\section{KONTAKT}

PhDr. Monika Adamická

Ústav stredoeurópskych jazykov a kultúr

Fakulta stredoeurópskych štúdií UKF v Nitre

Dražovská 4

94974 Nitra

Slovenská republika

monika.adamicka@ukf.sk 